\title{
Multiple-enzyme supplementation on digestive traits, carcass characteristics, blood lipid parameters and growth performance of broilers fed a wheat-based diet
}

\author{
Hamid Reza Taheri ${ }^{1, *}$ and Kayvan Shirzadegan ${ }^{1}$
}

\begin{abstract}
* Corresponding Author: Hamid Reza Taheri Tel: +98-24-3305-2243, Fax: +98-24-3305-2204, E-mail: taherihr@gmail.com
\end{abstract}

'Department of Animal Science, Faculty of Agriculture, University of Zanjan, Zanjan 45371-38791, Iran

Submitted May 27, 2016; Revised Sept 5, 2016; Accepted Sept 21, 2016
Objective: A trial was conducted from 11 to $42 \mathrm{~d}$ post-hatch to investigate the effectiveness of the supplementation of a multiple-enzyme preparation (Natuzyme Plus) in a wheat-based diet on digesta viscosity, $\mathrm{pH}$ and microbial population, villus morphology, feed passage time, nutrient retention, carcass characteristics, blood lipid parameters and growth performance of broiler chickens.

Methods: Three hundreds 10-d-old male Ross 308 chicks were allocated to three diets with five replicates of 20 birds per replicate. Dietary treatments were i) a wheat-based diet (W), ii) W+Natuzyme Plus (WN; $500 \mathrm{mg} / \mathrm{kg}$ of the diet), and iii) a corn-based diet (C).

Results: Birds fed on the $\mathrm{C}$ diet had higher average daily gain (ADG, $\mathrm{p}<0.01$ ), villus height $(\mathrm{VH}$, $\mathrm{p}<0.01)$, total tract apparent retention (TTAR) of nitrogen (NT, $\mathrm{p}<0.01)$ and ether extract (EE, $\mathrm{p}<0.01)$, nitrogen-corrected apparent metabolizable energy $\left(\mathrm{AME}_{\mathrm{n}}, \mathrm{p}<0.05\right)$, relative weight (RW, \% of body weight) of carcass ( $\mathrm{p}<0.05$ ), blood concentration of triglyceride (TG, on d 40 $[\mathrm{p}<0.01]$ ), total cholesterol (TC, on d $22[\mathrm{p}<0.05]$ ) and low density lipoprotein (LDL, on d 22 $[\mathrm{p}<0.01]$ and $40[\mathrm{p}<0.05])$, and also lower feed conversion ratio (FCR, $\mathrm{p}<0.01)$, digesta viscosity $(\mathrm{p}<0.01)$, count of coliforms $(\mathrm{p}<0.01)$ and Escherichia coli $(\mathrm{p}<0.01)$ and epithelium thickness (ET, p<0.05) than those fed on the W diet. ADG, FCR, VH, ET, TTAR of NT and EE, RW of carcass, blood concentration of TG (on d 40), TC (on d 22) and LDL (on d 22 and 40) values of the $\mathrm{WN}$ diet did not show a significant ( $\mathrm{p}>0.05$ ) difference compared to those of the $\mathrm{C}$ diet. Compared to those of the $\mathrm{W}$ diet, the $\mathrm{WN}$ diet showed the higher count of Lactobacilli and lower count of coliforms $(\mathrm{p}<0.01)$ and digesta viscosity $(\mathrm{p}<0.01)$.

Conclusion: In general, the results of this study showed that Natuzyme Plus supplementation in a wheat-based diet can be appropriate to achieve a comparable growth performance in broiler chickens to those given the $\mathrm{C}$ diet probably through improving digesta viscosity, $\mathrm{VH}, \mathrm{ET}$, TTAR of NT and EE, $\mathrm{AME}_{\mathrm{n}}$, count of Lactobacilli and coliforms.

Keywords: Broiler Chicken; Growth Performance; Natuzyme Plus; Wheat

\section{INTRODUCTION}

Wheat is commonly used as a major source of energy in poultry diets in some parts of the world $[1,2]$. However, it has lower energy content and provides more protein compared to corn. In addition, wheat has high soluble non-starch polysaccharides (S-NSP) content and one of the major challenges of feeding cereals with high level of S-NSP to chicks is the increase of viscosity in gut digesta and subsequent, slowing down the digesta passage rate, leading to proliferation of unfavorable fermentative organisms in the small intestine, which is detrimental especially to the villus [3]. In addition, increasing the digesta viscosity reduces the nutrient digestibility and growth performance of poultry $[4,5]$. Supplementation of the diet with exogenous enzymes $[6,7]$ is the most common strategy recommended to minimize the negative effect of S-NSP. 
Natuzyme Plus is one of the multiple enzyme preparations which contains cellulase, xylanase, $\beta$-glucanase, $\alpha$-amylase, pectinase, phytase, proteases (acid and neutral) and lipase. Evaluation of the efficiency of multiple enzyme-based preparations is of practical use and relevant to poultry industry [8]. Lee et al [8] investigated the effect of Natuzyme supplementation on performance of laying hens. Sharifi et al [9] examined the dietary supplementation of Natuzyme in broiler chickens, but they only investigated intestinal morphology and performance of chicks. Therefore, the aim of the present study was to investigate the effect of Natuzyme supplementation in a diet with a high level of wheat inclusion (i.e. 40\%) on digesta $\mathrm{pH}$ and microbial population of the intestine, feed passage time, nutrients retention and nitrogen-corrected apparent metabolizable energy $\left(\mathrm{AME}_{\mathrm{n}}\right)$ of diet, blood lipid parameters, relative weight (RW) of carcass and digestive tract organs, digesta viscosity, villus morphology and growth performance of broiler chickens from 11 to $42 \mathrm{~d}$ of age.

\section{MATERIALS AND METHODS}

\section{Birds and husbandry}

The experimental procedures described in this research were approved by the Animal Ethics Committee of the University of Zanjan and were conducted in a manner that avoided unnecessary discomfort to the birds by the use of proper management and laboratory techniques.

Day old male Ross 308 broiler chicks were housed in an environmentally controlled room and given a commercial starter diet and water ad libitum. At $11 \mathrm{~d}$ of age, three hundreds chicks were randomly distributed in groups of 20 in 15 litter-floored pens $(1.5 \times 1.5 \mathrm{~m})$. Mean body weight (BW) of the chicks in all pens was similar $(380 \pm 5 \mathrm{~g})$. The birds were given ad libitum access to water and diets and exposed to a 23L:1D cycle. Room temperature was kept at $32^{\circ} \mathrm{C}$ during the first three $\mathrm{d}$ of life and then, it was reduced gradually according to age until reaching $22^{\circ} \mathrm{C}$ at $24 \mathrm{~d}$ of age. This temperature was kept during 25 to $42 \mathrm{~d}$ of age.

\section{Experimental diets}

All diets were fed in mash form and met or exceeded the nutritional recommendations of Aviagen [10] for Ross 308 male broilers during 11 to 24 and 25 to $42 \mathrm{~d}$ of age (Table 1). Dietary treatments were i) a wheat-based $\operatorname{diet}(\mathrm{W})$, ii) W+Natuzyme Plus (WN) and iii) a corn-based diet (C). Natuzyme Plus Green Enzyme (Bioproton Pty Ltd., Sunnybank, Australia) was a powder form of cellulase $(6,000,000 \mathrm{U} / \mathrm{kg})$, xylanase $(10,000,000 \mathrm{U} / \mathrm{kg})$, $\beta$-glucanase $(700,000 \mathrm{U} / \mathrm{kg}), \alpha$-amylase $(700,000 \mathrm{U} / \mathrm{kg})$, pectinase $(70,000 \mathrm{U} / \mathrm{kg})$, phytase $(500,000 \mathrm{U} / \mathrm{kg})$, proteases (acid and neutral; 3,000,000 U/kg) and lipase (30,000 U/kg) and used $500 \mathrm{mg} / \mathrm{kg}$ of the diet. Each treatment was replicated five times and the experimental unit was a pen with 20 chicks.
Table 1. Ingredient composition, nutrient content and particle size distribution of the experimental diets (\%, as-fed basis, unless otherwise indicated)

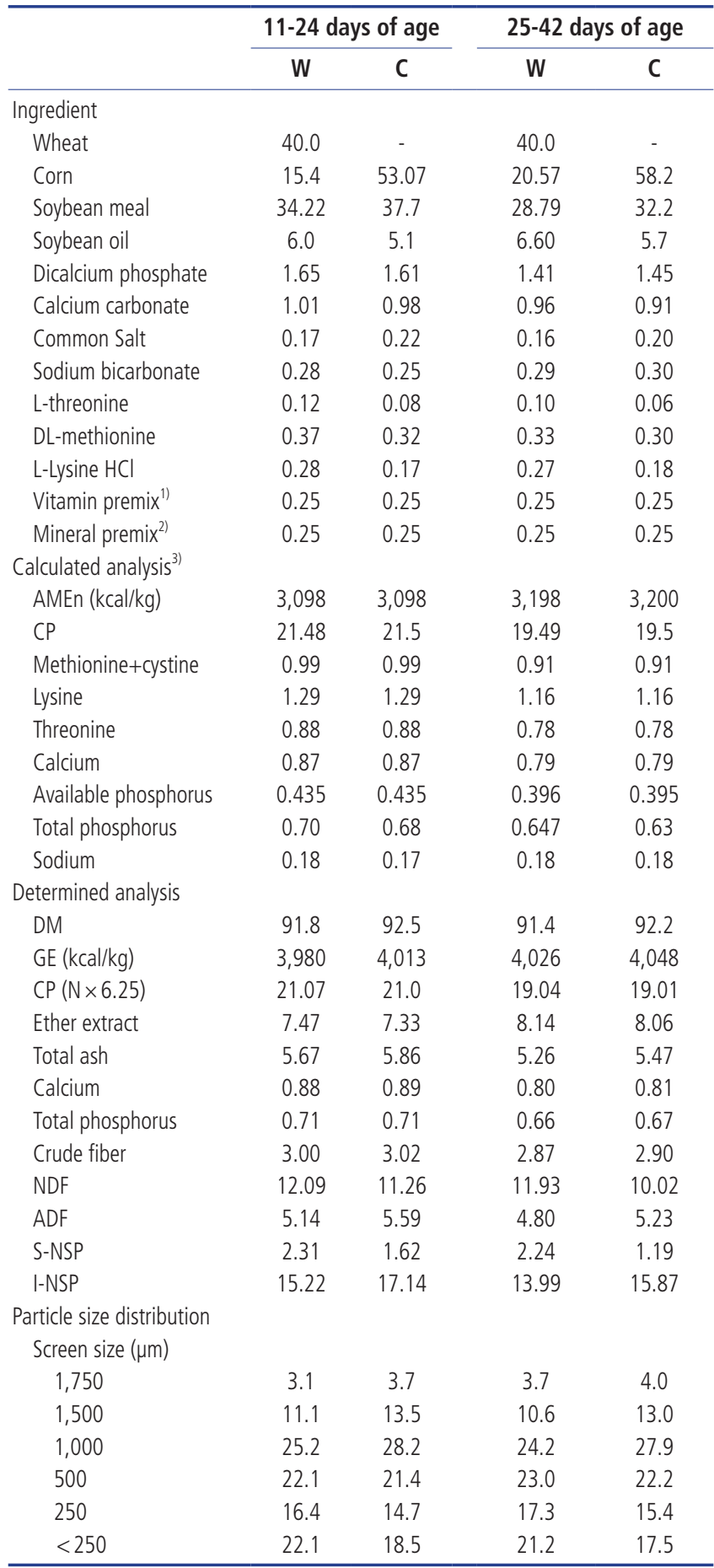

W, wheat-based diet; $C$, corn-based diet; $A M E_{n}$, nitrogen-corrected apparent metabolizable energy; $C P$, crude protein; DM, dry matter; GE, gross energy; NDF, neutral detergent fiber, ADF, acid detergent fiber; S-NSP, soluble non-starch polysaccharides; I-NSP, insoluble NSP.

1) Provided the following per kilogram of diets: vitamin $A, 9,000 \mathrm{IU}$ (retinyl acetate); cholecalciferol, 2,000 IU; vitamin E, $36 \mathrm{IU}$ (dl- $\alpha$-tocopheryl acetate); vitamin $\mathrm{B}_{12}, 0.015$ $\mathrm{mg}$; menadione, $2 \mathrm{mg}$; riboflavin, $6.6 \mathrm{mg}$; thiamine, $1.8 \mathrm{mg}$; pantothenic acid, $7.3 \mathrm{mg}$; niacin, $30 \mathrm{mg}$; folic acid, $1 \mathrm{mg}$; biotin, $0.1 \mathrm{mg}$; pyridoxine, $3 \mathrm{mg}$.

2) Provided the following per kilogram of diets: manganese $\left(\mathrm{MnSO}_{4} \cdot \mathrm{H}_{2} \mathrm{O}\right), 75 \mathrm{mg}$; zinc ( $\mathrm{ZnO}), 85 \mathrm{mg}$; iron $\left(\mathrm{FeSO}_{4} \cdot 7 \mathrm{H}_{2} \mathrm{O}\right), 50 \mathrm{mg}$; copper $\left(\mathrm{CuSO}_{4} \cdot 5 \mathrm{H}_{2} \mathrm{O}\right), 10 \mathrm{mg}$; selenium $\left(\mathrm{Na}_{2} \mathrm{SeO}_{3}\right), 0.2 \mathrm{mg}$; iodine (lodized $\left.\mathrm{NaCl}\right), 0.8 \mathrm{mg}$; choline, $250 \mathrm{mg}$.

${ }^{3)}$ According to NRC [23]. 
The body weight of chicks and feed consumption were determined by pen at 11, 24 and $42 \mathrm{~d}$ of age, and average daily gain (ADG), average daily feed intake (ADFI), and feed conversion ratio (FCR) were determined from 11 to 24,25 to 42 , and 11 to $42 \mathrm{~d}$ of age. Before weighing, the chicks were fasted for six $\mathrm{h}$ to ensure a consistent gut fill among all birds. Feed intake was adjusted for mortalities and the birds that killed at $36 \mathrm{~d}$ of age and their ADG was included in the calculation of FCR.

Microbial count of jejunum, villus morphology of jejunum, digesta viscosity of ileum and digesta $\mathrm{pH}$ of digestive tract At $36 \mathrm{~d}$ of age, three chicks/pen (15 chicks/treatment) were randomly selected, weighed individually, and killed by cervical dislocation. Jejunum was dissected and the contents of digesta were collected and pooled aseptically on the pen basis. The count of lactobacilli, coliforms and Escherichia coli (E. coli) were obtained by the plate culture method. Briefly, one g of jejunal digesta was sampled. The samples were serially diluted and plated on duplicate using Eosin Methylene-Blue agar media (Merck, Germany) to enumerate E. coli, MacConkey agar media (Merck, Germany) to enumerate coliforms, and Rogosa agar media (Merck, Germany) to enumerate lactobacilli. Plates were incubated at $37^{\circ} \mathrm{C}$ for 24 $\mathrm{h}$ aerobically (for the count of E. coli and coliforms) and $41^{\circ} \mathrm{C}$ for $72 \mathrm{~h}$ anaerobically (for the count of lactobacilli).

A segment (one $\mathrm{cm}$ ) at the midpoint of the jejunum was removed, washed in physiological saline solution, and fixed in $10 \%$ buffered formalin. The segments were embedded in paraffin, and a 2-mm section of each sample was placed on a glass slide and stained with haematoxylin and eosin for examination [11]. Histological sections were examined with a Nikon phase contrast microscope (Nikon Eclipse 80i, Nikon Corp., Tokyo, Japan). All sound views were measured in each intestinal section. Villus height $(\mathrm{VH})$ was measured from the top to the base, excluding the intestinal crypt, and crypt depth (CD) was defined as the distance from the villus base to the muscularis layer, not including the intestinal muscularis. The VH:CD ratio was calculated. Epithelium thickness (ET) was measured from the basement membrane to the bottom of the striated border in the central part of the villus. The average value of three birds/pen was used for statistical analysis.

Ileum was dissected and the contents of digesta were collected and pooled on a pen basis. The viscosity (in centipoise) of ileal digesta was measured according to the method of Yasar and Forbes [12] by a viscometer (Myr V2L, Viscotech, Tarragona, Spain) which was equipped with Brookfield circulator (Brookfield Engineering Laboratories., Middleboro, MA, USA).

Digesta of gizzard, duodenum, ileum and cecum were also collected and pooled on a pen basis. Digesta $\mathrm{pH}$ of these organs and the remaining digesta of jejunum were measured according to the procedure of Pang and Applegate [13] by a $\mathrm{pH}$ meter (Metrohm 713, Herisau, Switzerland).
Feed passage time, total tract apparent retention of nutrients

At $37 \mathrm{~d}$ of age, white-color trays were placed under the cages and, in all pens simultaneously, the experimental diets were replaced by similar diets to which $0.3 \%$ chromic oxide (a green-color powder) was added. Two hours after feeding the marker-included diets, the detection of green excreta in all pens was performed by a team of people every minute. Feed passage time was estimated as the time of first visual appearance of green color in the excreta. In order to measure the total tract apparent retention (TTAR) of nutrients, representative samples of excreta were collected daily by replicate on $\mathrm{d} 40$ and 41 . The TTAR of $\mathrm{N}$ and ether extract (EE) was calculated according to the following equation:

$$
\mathrm{TTAR}=\left\{1-\left[\left(\mathrm{Cr}_{\mathrm{fd}} / \mathrm{Cr}_{\mathrm{ex}}\right) \times\left(\mathrm{N}_{\mathrm{ex}} / \mathrm{N}_{\mathrm{fd}}\right)\right]\right\} \times 100
$$

Where $\mathrm{Cr}_{\mathrm{fd}}$ and $\mathrm{Cr}_{\mathrm{ex}}$ represent chromium in feed and excreta and $\mathrm{N}_{\mathrm{fd}}$ and $\mathrm{N}_{\mathrm{ex}}$ are the nutrients in feed and excreta, respectively. The $\mathrm{AME}_{\mathrm{n}}$ of the diets was calculated as indicated by Lázaro et al [7].

Relative weight and relative length of digestive tract organs and relative weight of carcass

On $\mathrm{d} 42$, after the weighing the birds in all pens, three chicks/pen were randomly selected, weighed individually, and killed by cervical dislocation. The digestive tract was removed, and the crop, proventriculus, gizzard, pancreas, duodenum, jejunum, ileum, ceca, and colon were excised. The weight of the empty organs was expressed relative to live BW to obtain the RW of these organs. In addition, the RW of carcass, breast, thigh+drumstick, heart, liver, pancreas, abdominal fat pad was also measured. The length of duodenum, jejunum, ileum, cecum and colon was expressed relative to live BW to obtain the $\mathrm{RL}$ of these organs. The average value of three birds/pen was used for statistical analysis.

\section{Blood lipid parameters}

At 22 and $40 \mathrm{~d}$ of age, three chicks/pen were randomly selected to obtain serum samples. The concentration of total cholesterol (TC), triglyceride (TG), and low density lipoprotein (LDL) was analyzed in duplicate using an auto analyzer (Bio Systems S.A.Costa Brava 30, 08030 Barcelona, Spain), following the kit instructions (Pars Azmon, Tehran, Iran). The average value of three birds/pen was used for statistical analysis.

\section{Analytical evaluation of ingredients, diets and excreta}

The ingredients and diets were analyzed for dry matter (930.15), total ash (942.05), calcium (968.08), total phosphorus (965.17) and crude fiber (978.10) concentrations according to the standard procedures of AOAC [14]. The ingredients, diets and excreta were analyzed for nitrogen (NT, 984.13) and EE (920.39) content according to the standard procedures of AOAC [14]. Neutral 
detergent fiber (NDF) and acid detergent fiber (ADF) concentrations of diets were determined as described by Van Soest et al [15]. Diets were analyzed for S-NSP and insoluble NSP (I-NSP) according to the procedure of Englyst et al [16]. Gross energy of diets and excreta were measured in an isoperibol bomb calorimeter (Parr 1356, Parr Instrument Co., Moline, IL, USA). Chromic oxide was determined by the method of Williams et al [17]. Particle size distribution of the experimental diets were determined using the different size of sieves $(250,500,750,1,000$, $1,500$, and $1,750 \mu \mathrm{m})$. All analyses were conducted in duplicate.

\section{Statistical analysis}

Data were analyzed as a completely randomized design using the general linear model procedure of SAS [18]. The experimental unit was the pen for all traits and differences among treatments were considered significant at $\mathrm{p}<0.05$ and tendencies at $0.05 \leq \mathrm{p}$ $\leq 0.15$. Significant differences between means were separated by Fisher's least significant difference (protected t-test).

\section{RESULTS AND DISCUSSION}

The effect of dietary treatments on ADFI, ADG and FCR is presented in Table 2. There was no significant difference $(\mathrm{p}>0.05)$ of ADFI among treatments, while Sharifi et al [9] found that a wheat-based diet plus Natuzyme and a corn-based diet had higher feed intake than that of the wheat-based diet. This discrepancy may be related to the diet concentration: the nutrients level in the current study was higher than those of the diets used in the work of Sharifi et al [9]. The birds receiving the $\mathrm{C}$ diet had higher ADG $(\mathrm{p}<0.01)$ and also lower FCR $(\mathrm{p}<0.01)$ than those feeding on the $\mathrm{W}$ diet during 11 to 24,25 to 42 , and 11 to $42 \mathrm{~d}$ of age.

Table 2. Effect of Natuzyme Plus ${ }^{1)}$ inclusion in wheat-based diet on growth performance of broiler chickens from 11 to $42 \mathrm{~d}$ of age

\begin{tabular}{cccccc}
\hline & W & WN & C & SEM & p-value \\
\hline ADFI (g) & & & & & \\
$11-24 d$ & 56.4 & 58.2 & 56.6 & 1.34 & 0.45 \\
$25-42 \mathrm{~d}$ & 161.5 & 166.0 & 163.0 & 2.60 & 0.31 \\
$11-42 \mathrm{~d}$ & 115.5 & 118.8 & 116.5 & 1.82 & 0.27 \\
ADG (g) & & & & & \\
$11-24 \mathrm{~d}$ & $32.9^{\mathrm{b}}$ & $38.7^{\mathrm{a}}$ & $36.6^{\mathrm{a}}$ & 0.95 & $<0.01$ \\
$25-42 \mathrm{~d}$ & $77.1^{\mathrm{b}}$ & $86.6^{\mathrm{a}}$ & $84.2^{\mathrm{a}}$ & 1.33 & $<0.01$ \\
$11-42 \mathrm{~d}$ & $57.7^{\mathrm{b}}$ & $65.5^{\mathrm{a}}$ & $63.4^{\mathrm{a}}$ & 1.02 & $<0.01$ \\
FCR (g:-g) & & & & & \\
$11-24 \mathrm{~d}$ & $1.72^{\mathrm{a}}$ & $1.50^{\mathrm{c}}$ & $1.55^{\mathrm{b}}$ & 0.015 & $<0.01$ \\
$25-42 \mathrm{~d}$ & $2.08^{\mathrm{a}}$ & $1.92^{\mathrm{b}}$ & $1.94^{\mathrm{b}}$ & 0.016 & $<0.01$ \\
$11-42 \mathrm{~d}$ & $2.00^{\mathrm{a}}$ & $1.81^{\mathrm{b}}$ & $1.83^{\mathrm{b}}$ & 0.015 & $<0.01$ \\
\hline
\end{tabular}

W, wheat-based diet; WN, wheat-based diet+Natuzyme Plus; C, corn-based diet; SEM, Standard error of the mean; $A D F I$, average daily feed intake; $A D G$, average daily gain; $F C R$, feed conversion ratio.

1) Natuzyme Plus was a powder form of cellulase $(6,000,000 \mathrm{U} / \mathrm{kg})$, xylanase $(10,000,000 \mathrm{U} / \mathrm{kg}), \beta$-glucanase $(700,000 \mathrm{U} / \mathrm{kg})$, a-amylase $(700,000 \mathrm{U} / \mathrm{kg})$, pectinase $(70,000 \mathrm{U} / \mathrm{kg})$, phytase $(500,000 \mathrm{U} / \mathrm{kg})$, proteases (acid and neutral; 3,000,000 U/kg) and lipase $(30,000 \mathrm{U} / \mathrm{kg})$ and used $500 \mathrm{mg} / \mathrm{kg}$ of the diet.

a-c Within a column, means without a common superscript differ $(p<0.05)$.
The ADG and FCR of the WN diet did not show a significant ( $p>0.05$ ) difference compared to those of the $\mathrm{C}$ diet. However, the $\mathrm{WN}$ diet showed a lower FCR than that of the $\mathrm{C}$ diet during 11 to $24 \mathrm{~d}$ of age. Sharifi et al [9] also found that Natuzyme supplementation improved weight gain and FCR compared to those fed on the diet without supplementation of this multienzyme. The beneficial effect of multiple-enzyme supplementation on growth performance of broiler chickens shows this supplement could overcome the negative effect of S-NSP in the W diet and enhance the nutrient digestibility generally. Some mechanisms relating to the improved performance of the $\mathrm{WN}$ and $\mathrm{C}$ diets compared to the $\mathrm{W}$ diet will be discussed in the following paragraphs.

The effect of dietary treatments on feed passage time, digesta viscosity, digesta $\mathrm{pH}$, microbial count and villus morphology of jejunum, TTAR of NT and EE and $\mathrm{AME}_{\mathrm{n}}$ of the diets are represented in Table 3. There was no significant $(p>0.05)$ difference of feed passage time among treatments, however, the $\mathrm{C}$ and $\mathrm{WN}$ diets tended ( $p=0.15)$ to decrease this parameter compared to that of the $\mathrm{W}$ diet. Although there is insufficient time for digestion and absorption of nutrients when the feed passage rate is too fast, too slow a passage rate of digesta has a problem with the accumulation of unfavorable bacteria. The birds receiving the $\mathrm{WN}$ diet showed a lower $(\mathrm{p}<0.01) \mathrm{pH}$ of gizzard digesta compared to those feeding on the $\mathrm{C}$ and $\mathrm{W}$ diets. Although there was no significant $(\mathrm{p}>0.05)$ difference of digesta $\mathrm{pH}$ in duodenum, jejunum and ileum among treatments, the $\mathrm{C}$ diet reduced $(\mathrm{p}<0.01)$ the digesta $\mathrm{pH}$ of cecum compared to that of the $\mathrm{W}$ and $\mathrm{WN}$ diets. The $\mathrm{C}$ and $\mathrm{WN}$ diets showed the reduced $(\mathrm{p}<0.01)$ digesta viscosity of jejunum compared to that of the $\mathrm{W}$ diet. This indicates that S-NSP content of the WN diet was hydrolyzed by the supplementation of Natuzyme Plus in the diet. The tendency to decrease the feed passage time in the $\mathrm{WN}$ and $\mathrm{C}$ diets may be due to the lower digesta viscosity observed in these treatments. However, the $\mathrm{C}$ diet had a lesser viscosity than that of the WN diet. The count of lactobacilli was higher $(p<0.05)$ for birds fed the $\mathrm{WN}$ diet than for birds fed the $\mathrm{W}$ diet with those fed the $\mathrm{C}$ diet being intermediate. The $\mathrm{C}$ and $\mathrm{WN}$ diets showed the decreased $(\mathrm{p}<0.01)$ count of coliforms compared to that of the $\mathrm{W}$ diet, however, the $\mathrm{C}$ diet had a lower count than that of the $\mathrm{WN}$ diet. The count of $E$. coli was lower $(\mathrm{p}<0.01)$ for birds fed the $\mathrm{C}$ diet than for those fed the W and WN diets. Since it has been indicated that faster feed passage rate and lower digesta viscosity reduce the available time for anaerobic bacteria to colonize in the distal part of the gastrointestinal tract, the improved microflora population in the $\mathrm{WN}$ and $\mathrm{C}$ diet in the current study may be related to these factors. It has been reported that increased digesta viscosity [3] and also fermentation and proliferation of unfavorable bacteria in the gut [19] mediate the magnitude of anti-nutritive effect of S-NSP in broiler chickens. Therefore, the better population of microflora may also be involved in the beneficial effect of Natuzyme Plus on growth performance of birds fed on the 
Table 3. Effect of Natuzyme Plus ${ }^{1)}$ inclusion in wheat-based diet on feed passage time, digesta pH of digestive tract, digesta viscosity, microbial count and villus morphology of jejunum, TTAR of nutrients, AME $E_{n}$ in broiler chickens

\begin{tabular}{|c|c|c|c|c|c|}
\hline & W & WN & C & SEM & $p$-value \\
\hline Feed passage time (min) & 263 & 248 & 239 & 11.5 & 0.15 \\
\hline Digesta viscosity (CP) & $5.92^{\mathrm{a}}$ & $4.38^{b}$ & $3.14^{c}$ & 0.405 & $<0.01$ \\
\hline \multicolumn{6}{|l|}{ Digesta $\mathrm{pH}$ of } \\
\hline Gizzard & $2.90^{\mathrm{a}}$ & $2.63^{b}$ & $3.00^{\mathrm{a}}$ & 0.076 & $<0.01$ \\
\hline Duodenum & 6.08 & 6.11 & 6.26 & 0.089 & 0.19 \\
\hline Jejunum & 6.18 & 6.17 & 6.14 & 0.051 & 0.75 \\
\hline lleum & 6.17 & 6.48 & 6.35 & 0.115 & 0.08 \\
\hline Cecum & $5.90^{\mathrm{a}}$ & $5.81^{\mathrm{a}}$ & $5.70^{b}$ & 0.041 & $<0.01$ \\
\hline \multicolumn{6}{|c|}{ Microbial count of jejunum ( $\log _{10}$ cfu/g of digesta) } \\
\hline Lactobacilli & $6.91^{b}$ & $7.46^{\mathrm{a}}$ & $7.09^{\mathrm{ab}}$ & 0.174 & $<0.05$ \\
\hline Coliforms & $7.67^{\mathrm{a}}$ & $7.37^{\mathrm{b}}$ & $7.06^{c}$ & 0.121 & $<0.01$ \\
\hline Escherichia coli & $6.12^{a}$ & $5.86^{\mathrm{a}}$ & $4.95^{b}$ & 0.194 & $<0.01$ \\
\hline \multicolumn{6}{|c|}{ Villus morphology of jejunum } \\
\hline $\mathrm{VH}(\mu \mathrm{m})$ & $830^{b}$ & $921^{\mathrm{a}}$ & $968^{\mathrm{a}}$ & 30.4 & $<0.01$ \\
\hline $\mathrm{CD}(\mu \mathrm{m})$ & 141 & 130 & 143 & 6.5 & 0.18 \\
\hline $\mathrm{VH}: \mathrm{CD}$ & 5.93 & 7.15 & 6.79 & 0.506 & 0.10 \\
\hline $\mathrm{ET}(\mu \mathrm{m})$ & $31.2^{\mathrm{a}}$ & $29.4^{\mathrm{ab}}$ & $28.2^{b}$ & 1.04 & $<0.05$ \\
\hline \multicolumn{6}{|l|}{$\operatorname{TTAR}(\%)$ of } \\
\hline Nitrogen & $68.4^{b}$ & $75.0^{\mathrm{a}}$ & $74.0^{\mathrm{a}}$ & 1.25 & $<0.01$ \\
\hline Ether extract & $65.9^{b}$ & $72.9^{\mathrm{a}}$ & $71.4^{\mathrm{a}}$ & 1.14 & $<0.01$ \\
\hline $\mathrm{AME}_{\mathrm{n}}(\mathrm{kcal} / \mathrm{kg})$ & $2,973^{b}$ & $3,177^{\mathrm{a}}$ & $3,135^{\mathrm{a}}$ & 58.3 & $<0.05$ \\
\hline
\end{tabular}

TTAR, total tract apparent retention; $\mathrm{AME}_{n}$, nitrogen-corrected apparent metabolizable energy; W, wheat-based diet; WN, wheat-based diet+Natuzyme Plus; C, corn-based diet; SEM, standard error of the mean; $\mathrm{VH}$, villus height; $\mathrm{CD}$, crypt depth; $\mathrm{VH}: \mathrm{CD}$, villus height to crypt depth ratio; $E T$, epithelium thickness.

1) Natuzyme Plus was a powder form of cellulase $(6,000,000 \mathrm{U} / \mathrm{kg})$, xylanase $(10,000,000 \mathrm{U} / \mathrm{kg}), \beta$-glucanase $(700,000 \mathrm{U} / \mathrm{kg})$, $\alpha$-amylase $(700,000 \mathrm{U} / \mathrm{kg})$, pectinase $(70,000 \mathrm{U} / \mathrm{kg})$, phytase $(500,000 \mathrm{U} / \mathrm{kg})$, proteases (acid and neutral; $3,000,000 \mathrm{U} / \mathrm{kg}$ ) and lipase $(30,000 \mathrm{U} / \mathrm{kg})$ and used $500 \mathrm{mg} / \mathrm{kg}$ of the diet.

a-c Within a column, means without a common superscript differ $(p<0.05)$.

$\mathrm{WN}$ and $\mathrm{C}$ diet in the present experiment, since the supplementation of Natuzyme Plus caused the lower digesta viscosity and coliform count and the increased population of Lactobacilli. The result of digesta viscosity was in agreement with the research of Sharifi et al [9] who reported the lower digesta viscosity in the ileum. The $\mathrm{C}$ diet showed a higher $(\mathrm{p}<0.01) \mathrm{VH}$ than that of the $\mathrm{W}$ diet. The $\mathrm{VH}$ of the $\mathrm{WN}$ diet did not show a significant ( $\mathrm{p}>$ 0.05 ) difference compared to that of the $\mathrm{C}$ diet. There was no significant difference ( $p>0.05)$ of $\mathrm{CD}$ among treatments, however, the $\mathrm{C}$ and $\mathrm{WN}$ diets tended $(\mathrm{p}=0.1)$ to increase this parameter compared to that of the $\mathrm{W}$ diet. The ET was lower $(\mathrm{p}<0.05)$ for birds fed the $\mathrm{C}$ diet than for birds fed the $\mathrm{W}$ diet with those fed the $\mathrm{WN}$ diet being intermediate. Montagne et al [20] reported that the presence of highly viscous digesta increases the rate of villus cell losses leading to villus atrophy and Cook [21] indicated that the elevated population of microflora enhances gut wall thickness. In the current research, the improvement in the $\mathrm{VH}$ and ET might be another explanation for the better growth performance and nutrients retention of the birds fed on the diet supplemented with Natuzyme Plus. The birds receiving the $C$ diet had higher TTAR of NT $(p<0.01)$ and EE $(p<0.01)$ and $\mathrm{AME}_{n}$ $(\mathrm{p}<0.05)$ than those feeding on the $\mathrm{W}$ diet. The TTAR of NT and $\mathrm{EE}$ and also $\mathrm{AME}_{\mathrm{n}}$ of the $\mathrm{WN}$ diet did not show a significant ( $p>0.05$ ) difference compared to those of the $\mathrm{C}$ diet. It has been reported that high digesta viscosity reduces the diffusion rate of nutrients and digestive tract enzymes and obstructs their interaction at the mucosal surface [22] and subsequently decreases the nutrient digestibility $[4,5]$. The increased population of unfavorable microflora in the gut of the birds fed the high-viscous diets may be involved in the reduced availability of nutrients to the absorption area. For example, the unfavorable microflora can hydrolyze the bile salts and decrease fat digestibility. The measured $\mathrm{AME}_{\mathrm{n}}$ of the $\mathrm{W}$ diet was lower than that of the calculated one. This reduction can be due to the variety of wheat used in the current experiment. The calculated $\mathrm{AME}_{\mathrm{n}}$ of the diets was based on the data of NRC [23], but it has been indicated that different varieties of wheat have different energy content and characteristics, because they have different nutrient levels and S-NSP content [24].

The effect of dietary treatments on the RW of empty digestive tract organs and the RL of intestine and cecum are represented in Table 4 . There was no significant difference $(p>0.05)$ of the RW of crop, proventriculus, gizzard, duodenum, jejunum and colon among treatments. The $\mathrm{C}$ diet showed the decreased RW of ileum, whole intestine and ceca compared to those of the W diet, however, the $\mathrm{WN}$ diet did not have a significant $(\mathrm{p}>0.05)$ difference compared to those of the $\mathrm{C}$ diet. There was no significant difference ( $p>0.05)$ of the RL of duodenum, ileum and colon among treatments. However, the RL of whole intestine of the C and $\mathrm{WN}$ diets tended $(\mathrm{p}=0.1)$ to decrease this parameter com- 
Table 4. Effect of Natuzyme Plus ${ }^{1)}$ inclusion in wheat-based diet on the relative weight of empty digestive tract and the relative length of intestine and cecum in broiler chickens

\begin{tabular}{lccccr}
\hline & W & WN & C & SEM & p-value \\
\hline Relative weight (\% live BW) & & & & & \\
$\quad$ Crop & 0.51 & 0.50 & 0.50 & 0.022 & 0.23 \\
Proventriculus & 0.52 & 0.52 & 0.51 & 0.013 & 0.73 \\
Gizzard & 2.29 & 2.20 & 2.23 & 0.091 & 0.65 \\
Duodenum & 0.74 & 0.73 & 0.69 & 0.024 & 0.17 \\
Jejunum & 1.77 & 1.69 & 1.63 & 0.124 & 0.59 \\
Ileum & $1.28^{\mathrm{a}}$ & $1.06^{\mathrm{b}}$ & $1.06^{\mathrm{b}}$ & 0.076 & $<0.05$ \\
Whole intestine ${ }^{2)}$ & $5.20^{\mathrm{a}}$ & $4.73^{\mathrm{b}}$ & $4.61^{\mathrm{b}}$ & 0.187 & $<0.05$ \\
Ceca & $0.89^{\mathrm{a}}$ & $0.75^{\mathrm{b}}$ & $0.71^{\mathrm{b}}$ & 0.059 & $<0.05$ \\
Colon & 0.52 & 0.50 & 0.52 & 0.011 & 0.12 \\
Relative length (cm/kg live BW) & & & & & \\
Duodenum & 15.6 & 14.7 & 14.1 & 1.09 & 0.48 \\
Jejunum & $37.9^{\mathrm{a}}$ & $36.3^{\mathrm{ab}}$ & $34.1^{\mathrm{b}}$ & 1.13 & $<0.05$ \\
Ileum & 23.7 & 24.2 & 23.5 & 0.79 & 0.72 \\
Whole intestine & 83.4 & 81.3 & 77.8 & 2.20 & 0.10 \\
Cecum & $15.9^{\mathrm{a}}$ & $13.1^{\mathrm{b}}$ & $13.3^{\mathrm{b}}$ & 0.64 & $<0.01$ \\
Colon $^{\text {Colon }}$ & 6.2 & 6.2 & 6.1 & 0.13 & 0.87 \\
\hline
\end{tabular}

W, wheat-based diet; WN, wheat-based diet+Natuzyme Plus; C, corn-based diet; SEM, standard error of the mean; BW, body weight.

1) Natuzyme Plus was a powder form of cellulase $(6,000,000 \mathrm{U} / \mathrm{kg})$, xylanase $(10,000,000 \mathrm{U} / \mathrm{kg}), \beta$-glucanase $(700,000 \mathrm{U} / \mathrm{kg})$, $\alpha$-amylase $(700,000 \mathrm{U} / \mathrm{kg})$, pectinase $(70,000 \mathrm{U} / \mathrm{kg})$, phytase $(500,000 \mathrm{U} / \mathrm{kg})$, proteases (acid and neutral; 3,000,000 U/kg) and lipase $(30,000 \mathrm{U} / \mathrm{kg})$ and used $500 \mathrm{mg} / \mathrm{kg}$ of the diet.

2) Duodenum+jejunum+ileum+ceca+colon.

${ }^{3)}$ Duodenum+jejunum+ileum+colon.

a,b Within a column, means without a common superscript differ $(p<0.05)$.

pared to that of the $\mathrm{W}$ diet, and the RL of jejunum was lower $(\mathrm{p}<0.05)$ for birds fed the $\mathrm{C}$ diet than for birds fed the $\mathrm{W}$ diet with those fed the $\mathrm{WN}$ diet being intermediate. The $\mathrm{C}$ and $\mathrm{WN}$ diets showed a decreased $(\mathrm{p}<0.01) \mathrm{RL}$ of cecum compared to that of the $\mathrm{W}$ diet.

The effect of dietary treatments on the RW of carcass, breast, thigh+drumstick, heart, liver and pancreas are represented in Table 5. There was no significant difference $(\mathrm{p}>0.05)$ of the RW

Table 5. Effect of Natuzyme Plus ${ }^{1)}$ inclusion in wheat-based diet on the relative weight (\% live BW) of carcass, breast, thigh+drumstick, heart, liver, pancreas, abdominal fat pad in broiler chickens

\begin{tabular}{lccccc}
\hline & W & WN & C & SEM & p-value \\
\hline Carcass & $72.7^{\mathrm{b}}$ & $74.0^{\mathrm{a}}$ & $73.9 \mathrm{a}$ & 0.45 & $<0.05$ \\
Breast & 27.6 & 27.2 & 27.3 & 0.49 & 0.83 \\
Thigh+drumstick & 25.0 & 25.4 & 24.9 & 0.38 & 0.46 \\
Heart & $0.45^{\mathrm{a}}$ & $0.41^{\mathrm{b}}$ & $0.42 \mathrm{~b}$ & 0.012 & $<0.05$ \\
Liver & $2.58^{\mathrm{a}}$ & $2.36^{\mathrm{b}}$ & $2.34 \mathrm{~b}$ & 0.059 & $<0.01$ \\
Pancreas & $0.30^{\mathrm{a}}$ & $0.23^{\mathrm{b}}$ & $0.22 \mathrm{~b}$ & 0.013 & $<0.01$ \\
Abdominal fat pad & 1.95 & 1.89 & 1.95 & 0.037 & 0.28 \\
\hline
\end{tabular}

BW, body weight; W, wheat-based diet; WN, wheat-based diet+Natuzyme Plus; C, cornbased diet; SEM, standard error of the mean.

1) Natuzyme Plus was a powder form of cellulase $(6,000,000 \mathrm{U} / \mathrm{kg})$, xylanase $(10,000,000 \mathrm{U} / \mathrm{kg}), \beta$-glucanase $(700,000 \mathrm{U} / \mathrm{kg})$, a-amylase $(700,000 \mathrm{U} / \mathrm{kg})$, pectinase $(70,000 \mathrm{U} / \mathrm{kg})$, phytase $(500,000 \mathrm{U} / \mathrm{kg})$, proteases (acid and neutral; 3,000,000 U/kg) and lipase $(30,000 \mathrm{U} / \mathrm{kg})$ and used $500 \mathrm{mg} / \mathrm{kg}$ of the diet.

a,b Within a column, means without a common superscript differ $(p<0.05)$. of breast and thigh+drumstick among treatments. The birds receiving the $\mathrm{C}$ and $\mathrm{WN}$ diets showed the higher $(\mathrm{p}<0.05) \mathrm{RW}$ of carcass compared to those feeding on the $\mathrm{W}$ diet, however, the $\mathrm{WN}$ diet did not show a significant ( $\mathrm{p}>0.05$ ) difference compared to that of the $\mathrm{C}$ diet. The $\mathrm{C}$ diet showed the lower RW of heart $(\mathrm{p}<0.05)$, liver $(\mathrm{p}<0.01)$ and pancreas $(\mathrm{p}<0.01)$ compared to those of the $\mathrm{W}$ diet, however, the $\mathrm{WN}$ diet did not have a significant ( $p>0.05$ ) difference compared to those of the $\mathrm{C}$ diet.

The effect of dietary treatments on serum TG, TC, and LDL is represented in Table 6. There was no significant difference ( $\mathrm{p}>$ 0.05 ) of serum TG among treatments on $\mathrm{d} 22$. At $40 \mathrm{~d}$ of age, the $C$ diet showed a higher $(p<0.01)$ serum TG than that of the W diet, however, the $\mathrm{WN}$ diet did not have a significant $(\mathrm{p}>0.05)$ difference compared to that of the $\mathrm{C}$ diet. On $\mathrm{d} 22$, the serum TC was higher $(\mathrm{p}<0.05)$ for birds fed the $\mathrm{C}$ diet than for birds fed the $\mathrm{W}$ diet with those fed the $\mathrm{WN}$ diet being intermediate. However, at $40 \mathrm{~d}$ of age, the $\mathrm{C}$ and $\mathrm{WN}$ diets tended $(\mathrm{p}=0.1)$ to increase the serum TC compared to that of the $\mathrm{W}$ diet. On $\mathrm{d}$ 22 , the birds receiving the $\mathrm{C}$ diet showed the higher $(\mathrm{p}<0.01)$ serum LDL than those feeding on the $\mathrm{W}$ diet, however, the WN diet did not show a significant $(\mathrm{p}>0.05)$ difference compared to that of the $\mathrm{C}$ diet. At $40 \mathrm{~d}$ of age, the serum LDL was higher $(\mathrm{p}<0.05)$ for birds fed the $\mathrm{C}$ diet than for birds fed the $\mathrm{W}$ diet with those fed the $\mathrm{WN}$ diet being intermediate. The high viscous diet reduces the serum cholesterol and TG concentration in broiler chickens through the increased bile salts hydrolyzation and excretion into the faeces [25] and decreases the efficiency of bile salts to solublize lipids in the gut [26]. The increase in the serum TG (at $40 \mathrm{~d}$ of age) and LDL (at $22 \mathrm{~d}$ of age) concentration in broilers fed the diet supplemented by the Natuzyme Plus may be related to hindering the anti-nutritive effect of S-NSP. The result of TTAR of EE supports this idea, because the birds fed on the WN diet showed $10.6 \%$ improvement in the TTAR

Table 6. Effect of Natuzyme Plus ${ }^{11}$ inclusion in wheat-based diet on blood lipid parameters $(\mathrm{mg} / \mathrm{dL})$ in broiler chickens

\begin{tabular}{cccccc}
\hline & W & WN & C & SEM & p-value \\
\hline TG & & & & & \\
$22 d$ & 96.0 & 89.0 & 95.0 & 8.42 & 0.72 \\
$40 d$ & $103.8^{b}$ & $127.6^{\mathrm{a}}$ & $132.4^{\mathrm{a}}$ & 6.67 & $<0.01$ \\
TC & & & & & \\
$22 \mathrm{~d}$ & $84.0^{\mathrm{b}}$ & $92.6^{\mathrm{ab}}$ & $105.2^{\mathrm{a}}$ & 7.45 & $<0.05$ \\
$40 \mathrm{~d}$ & 135.8 & 152.0 & $147.2^{2}$ & 6.65 & 0.10 \\
LDL & & & & & \\
$22 \mathrm{~d}$ & $34.0^{\mathrm{b}}$ & $48.2^{\mathrm{a}}$ & $54.2^{\mathrm{a}}$ & 4.99 & $<0.01$ \\
$40 \mathrm{~d}$ & $45.2^{\mathrm{b}}$ & $56.2^{\mathrm{ab}}$ & $65.4^{\mathrm{a}}$ & 7.22 & $<0.05$ \\
\hline
\end{tabular}

W, wheat-based diet; WN, wheat-based diet+Natuzyme Plus; C, corn-based diet; SEM, standard error of the mean; TG, triglyceride; TC, total cholesterol; LDL, Low density lipoprotein.

1) Natuzyme Plus was a powder form of cellulase $(6,000,000 \mathrm{U} / \mathrm{kg})$, xylanase $(10,000,000 \mathrm{U} / \mathrm{kg}), \beta$-glucanase $(700,000 \mathrm{U} / \mathrm{kg})$, a-amylase $(700,000 \mathrm{U} / \mathrm{kg})$, pectinase $(70,000 \mathrm{U} / \mathrm{kg})$, phytase $(500,000 \mathrm{U} / \mathrm{kg})$, proteases (acid and neutral; 3,000,000 U/kg) and lipase $(30,000 \mathrm{U} / \mathrm{kg})$ and used $500 \mathrm{mg} / \mathrm{kg}$ of the diet.

$a, b$ Within a column, means without a common superscript differ $(p<0.05)$. 
of EE compared to those fed on the $\mathrm{W}$ diet.

The results of this study showed that Natuzyme Plus supplementation in a wheat-based diet can be appropriate to achieve a comparable growth performance in broiler chickens to those given the $\mathrm{C}$ diet probably through improving the digesta viscosity, $\mathrm{VH}, \mathrm{ET}$, TTAR of NT and EE, $\mathrm{AME}_{\mathrm{n}}$, the count of Lactobacilli and coliforms.

\section{CONFLICT OF INTEREST}

We certify that there is no conflict of interest with any financial organization regarding the material discussed in the manuscript.

\section{REFERENCES}

1. Kan CA, Hartnell GF. Evaluation of broiler performance when fed roundupready wheat, control and commercial wheat varieties. Poult Sci 2004;83:1325-34.

2. Wang ZR, Qiao SY, Lu WQ, Li DF. Effects of enzyme supplementation on performance, nutrient digestibility, gastrointestinal morphology, and volatile fatty acid profiles in the hindgut of broilers fed wheatbased diet. Poult Sci 2005;84:875-81.

3. Choct M, Hughes RJ, Wang J, et al. Increased small intestinal fermentation is partly responsible for the anti-nutritive activity of non-starch polysaccharides in chickens. Br Poult Sci 1996;37:609-21.

4. Nahas J, Lefrançois MR. Effects of feeding locally grown whole barley with or without enzyme addition and whole wheat on broiler performance and carcass traits. Poult Sci 2001;80:195-202.

5. Jozefiak D, Rudkowski A, Martin SA. Carbohydrate fermentation in the avian ceca: a review. Anim Feed Sci Technol 2004;113:1-15.

6. Gracía MI, Latorre MA, García M, Lázaro R, Mateos, GG. Heat processing of barley and enzyme supplementation of diets for broilers. Poult Sci 2003;87:1281-91.

7. Lázaro R, García M, Medel P, Mateos GG. Influence of enzymes on performance and digestive parameters of broilers fed rye-based diets. Poult Sci 2003;82:132-40.

8. Lee KW, Choi YI, Moon EJ, et al. Evaluation of dietary multiple enzyme preparation (Natuzyme) in laying hens. Asian-Australas J Anim Sci 2014;27:1749-54.

9. Sharifi SD, Golestani G, Yaghobfar A, Khadem A, Pashazanussi H. Effects of supplementing a multienzyme to broiler diets containing a high level of wheat or canola meal on intestinal morphology and performance of chicks. J Appl Poult Res 2013;22:671-9.

10. Aviagen, Ross 308: Broiler Nutrition Specification. Newbridge, Midlothian, UK: Ross Breeders Ltd; 2014.

11. Sakamoto K, Hirose H, Onizuka A, et al. Quantitative study of changes in intestinal morphology and mucus gel on total parenteral nutrition in rats. J Surg Res 2000;94:99-106.

12. Yasar S, Forbes JM. Enzyme supplementation of dry and wet wheatbased feeds for broiler chickens: performance and gut responses. Br J Nutr 2000;84:297-307.

13. Pang, Y, Applegate TJ. Effects of dietary copper supplementation and copper source on digesta $\mathrm{pH}$, calcium, zinc, and copper complex size in the gastrointestinal tract of the broiler chicken. Poult Sci 2007;86:531-7.

14. AOAC, Official Methods of Analysis. 17th ed. Association of Official Analytical Chemists, Arlington, VA: AOAC International; 2000.

15. Van Soest PJ, Robertson JB, Lewis BA. Methods for dietary fiber, neutral detergent fiber and non-starch polysaccharides in relation to animal nutrition. J Dairy Sci 1991;74:3583-97.

16. Englyst HN, Quigley ME, Geoffrey JH. Determination of dietary fibre as non-starch polysaccharides with gas-liquid chromatographic, high-performance liquid chromatographic or spectrophotometric measurement of constituent sugars. Analyst 1994;119:1497-509.

17. Williams CH, David DJ, Iisma O. The determination of chromic oxide in faeces samples by atomic absorption spectrometry. J Agric Sci 1962;59:381-5.

18. SAS (SAS Analysis System) Institute Inc. SAS User's Guide: Version 9.1. Cary, NC: SAS Institute Inc.; 2003.

19. Langhout DJ, Schutte JB, De Jong J, et al. Effect of viscosity on digestion of nutrients in conventional and germ-free chicks. Br J Nutr 2000;83: 533-40.

20. Montagne L, Pluske JR, Hampson DJ. A review of interactions between dietary fiber and the intestinal mucosa, and their consequences on digestive health in young non-ruminant animals. Anim Feed Sci Technol 2003;108:95-117.

21. Cook ME. Antibodies: alternatives to antibiotics in improving growth and feed efficiency. J Appl Poult Res 2004;13:106-19.

22. Ikegami S, Tsuchihashi F, Harada $H$, et al. Effect of viscous indigestible polysaccharides on pancreatic biliary secretion and digestive organs in rats. J Nutr 1990;120:353-60.

23. National Research Council, Nutrient requirements of poultry. 9th ed. Washington DC,: National Academy Press; 1994.

24. Amerah, AM. Interactions between wheat characteristics and feed enzyme supplementation in broiler diets. Anim Feed Sci Technol 2015;199:1-9.

25. Moundras C, Behr SR, Remesy C, Demigne C. Fecal losses of sterols and bile acids induced by feeding rat's guar gum are due to greater pool size and liver bile acid secretion. J Nutr 1997;127:1068-76.

26. Taheri HR, Tanha N, Shahir MH. Effect of wheat bran inclusion in barley-based diet on villus morphology of jejunum, serum cholesterol, abdominal fat and growth performance of broiler chicken. J Livest Sci Technol 2016;4:9-16. 